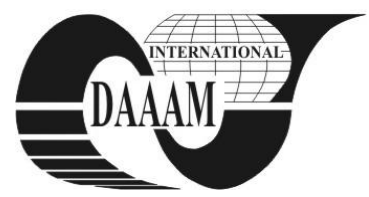

Annals of DAAAM for 2011 \& Proceedings of the 22nd International DAAAM Symposium, Volume 22, No. 1, ISSN 1726-9679 ISBN 978-3-901509-83-4, Editor B. Katalinic, Published by DAAAM International, Vienna, Austria, EU, 2011 Make Harmony between Technology and Nature, and Your Mind will Fly Free as a Bird Annals \& Proceedings of DAAAM International 2011

\title{
MAIN INFLUENCE AFFECTING PROFESSIONAL DEFENCE SOLUTION AND RESULT
}

\author{
MALANIK, Z[denek]
}

\begin{abstract}
This article deals with the main influences affecting professional defence solutions and results from the point of view of a worker in the commercial security industry. The time factor and its determinants are treated in more detail. This article emphasises the irreplaceable role of a human being - (a worker in the commercial security industry). Such a person is the only one who is capable of solving the problems of professional defence correctly and in time. The ways of subduing certain situations in professional defence are analysed from the point of view of the security worker and should aim at preventing criminality and detaining the suspect. The main influences affecting professional defence solutions and results are presented and analysed as a way to enable understanding, organisation and execution of this issue better Key words: professional defence, situations in professional defence, self-defence, physical defence
\end{abstract}

\section{INTRODUCTION}

There are lots of influences affecting the professional defence solution. Laypeople as well as some experts tend to favour some factors over other ones. In spite of that, the majority of situations in professional defence are in many ways similar to each other and the variety of influences is narrowed only to the basic ones. Those are: methods, ways, factors, aspects and perspectives of the professional defence solution.

\section{METHODS OF SOLVING A SITUATION}

The basic methods of solving a situation in professional defence may be differentiated from the point of view of expertise. They are the lay and expert methods of solving a situation in professional defence.

\subsection{Layman's Methods of Solving a Situation in Professional Defence}

Professional defence solutions include congenital conditions, educational environment, observed manners and the influence of inflammatory situations. The congenital conditions are, for example height and others Educational environment is crucial and it influences mainly a person's peacefulness, competitiveness, aggressiveness, respect for rules and control and respect for health and life. The observed manners may influence the professional defence solutions by way of overlooking or neglecting a situation, also recession and the use of aggressiveness in the form of shouting, arguments, conflicts and violence. The inflammatory situation atmosphere affects mainly the standard of shock reaction, stress and fear. An untrained worker in the commercial security industry generally freezes, is not capable of a correct and quick reaction Such a worker may even breakdown or submit to the aggressor. The opposite end of the reaction spectrum is the escalated aggression of the defender, significantly aggravated courage, intensification of the trust in oneself, one's own truth, justice, sacrifice for others, etc.

\subsection{Expert Methods of Solving a Situation in Professional Defence}

Professional defence solutions include the assertion of special knowledge and skills. The reality based system, martial sport or martial arts must be asserted. The most suitable reality based systems for use within the CSI are Systema, FISFO and Krav Maga. Karate, Kick Boxing and jiu Jitsu techniques may be used for professional defence as well as other martial arts. One may also apply techniques from the following martial arts: Wing Tsun, Hapki Do, Chen Tai Tchi or Ai Ki Do.

\section{WAYS OF SOLVING A SITUATION}

The professional defence solution has seven main forms. They are: prevention, recession, agreement, threat, fight, detention, and treatment of consequences of the situation.

\subsection{Prevention}

Is a strategic activity involving a whole range of organizational measures. The emphasis is on risk specification and using the best ways of anticipating risks and solving them. The main points are not to provoke the beginning of an attack, to avoid the attack, have good protective measures and have training in non physical professional defence solutions. Prevention is the primary task of physical defence in the CSI.

\subsection{Recession}

Follows from preventive measures which have little effect. It is usually a simple recession with no account of the aggressor's behaviour and actions. Of course, the worker must perform his. The recession may also take the form of escape from the place where the situation is occurring.

\subsection{Agreement}

An agreement with the aggressor may precede the recession or replace it. If needed it may be executed with other forms of professional defence solutions. It is usually a verbal, positional, material or combined agreement. A comparison of "gains and losses" is usually carried out. The agreement may be achieved through good communication skills.

\subsection{Threat}

A threat occurs when the preceding techniques fail or are absent. A threat may occur in the course of a fight or detention. It usually has the form of a communicated threat, the determination to fight, and the demonstration of power. The demonstration of power is the highest level of threat and it takes the form of a mastered presentation of professional defence techniques either on an object or on one of the aggressors.

\subsection{Fight}

A physical fight is started when other ways of solving the situation have failed or could not be used. A fight is carried out with all devices and all methods available with the aim of 
subduing the attack and eventually detaining the aggressor. It all must be in accordance with the postulates of professional defence and the law.

\subsection{Detention}

Detention is a professional defence solution, which can be used at any moment to treat the situation. Detention is carried out either when the subject cooperates, or when the subject does not cooperate, but does not attack or does not cooperate and attacks The manner of detention must be in accordance with the circumstances, especially with the conduct and action of the person being detained. Detention, as a part of professional defence solutions, is the second task of physical defence in the CSI.

\subsection{Ways of Solving Situations in Professional Defence}

This is the operational activity. It impacts on the immediate future of the defender, his employer and his profession. Considerations include such things as what happened, where, when, how and why it happened. Furthermore, it deals with who caused it, who was harmed and what harm occurred. The most important of these is prevention, the fight and the correct treatment of the consequences of the situation.

\section{FACTORS}

There are four crucial factors essentially influencing the professional defence solution. These are: the direction of the attack, timing, forces and devices, and the environment.

\subsection{Direction of Attack}

This is the most important element of professional defence. Without noting the direction of the attack, professional defence will always be ineffective. The attack may be aimed at the front, side and back area including the upper, middle and lower zone.

\subsection{Timing}

Timing is crucial to professional defence. This is so, mainly from the point of view of the distance from the aggressor, the seriousness of the situation, the intensity and the manner of attack.

\subsection{Forces and Devices}

These influence the solution of the situation in professional defence in the form of condition (health, psyche), weapons and devices, equipment, number of people involved.

\subsection{Environment}

The environment influences the solution of the situation in professional defence in the form of location, season and time of the day and inspection. These basic elements of professional defence work and intensify together; the order may change in each situation.

\section{ASPECTS}

There are three basic and very important aspects of the professional defence solution. They are the personal, social and legal aspects.

\subsection{Personal Aspect}

Is the most important aspect of professional defence. The quickest reaction and thus elimination of the harm caused by a person's attack is possible only within the scope of the personal aspect. There is no time for other aspects when the given situation is in this phase. Everything starts and ends, without further consequences.

\subsection{Social Aspect}

Is the second aspect influencing the consequences of the professional defence solution. It falls within the operational level. It appears at or immediately after the end of the situation. Witnesses, evidentiary materials from cameras, the attitude of the media, management, close people, and interest groups are included in this aspect. The social aspect may influence the worker in the CSI and the legal aspect in a positive or negative way. They usually work on behalf of the defender - the worker in the CSI.

\subsection{Legal Aspect}

Is the last to influence the professional defence solution. It falls within the operational, sometimes strategic, level of professional defence. It always appears at the end of the situation in question. It deals with the consequences of the professional defence solution from the legal perspective, generally a long time after the incident The consequences of a situation in professional defence are dealt with more frequently by the laymen and theoreticians than by the experts. Justice is not assured and it is necessary to be well prepared when approaching the legal aspect of the situation in the professional defence. These aspects may have an impact on the worker personally as well as on the private security company and the commercial security industry as a whole.

\section{CONCLUSION}

The basic given methods of the professional defence solution may be further divided; moreover they may be carried out consecutively, in combinations and may also blend together. The professional defence solution may have various perspectives and may supplement each other or blend together. The attention of the management of a private security company should be paid to the expert methods of the professional defence solution. Prevention, recession, agreement, threat, fight, detention and treating the consequences of the professional defence solution are basic forms of solutions, and varieties and combinations may be further derived from them. It is necessary to attend to the most important of them - that is the prevention and fight, detention and correct treatment of the consequence of the situation. Direction of an attack is the most important element of professional defence. However, all the basic elements of professional defence always work and escalate together. Their order may change according to the individual situation. The aspects of the professional defence solution immediately concern the present and future of the worker in the CSI as well as the whole commercial security industry. The professional defence solution perspectives may vary. The operational and strategic perspective is very important in professional defence, because of the quality of the service and the influence of such quality on the development of the CSI as a whole.

\section{REFERENCES}

Adams, J. a kol. (2001). Jak přežit v betonové džungli (Street Survival: Tactic for Armed Encounters), Armex, ISBN 8086244-19-9, Praha

Gruber, D.: (2005). Zlatá kniha komunikace (The Handbook of Communication), Repronis, ISBN 80-7329-092-8, Ostrava

Konečný, A. (1997). Sebeobrana a úpolová cvičení pro pokročilé (Self-defence and Resistance Exercise for Advanced), Univerzita Palackého, ISBN 80-7067-766-x, Olomouc

Náchodský, Z. (2006). Nebojte se bránit (Do not be Afraid to Defend Yourselves), Armex Publishing, ISBN 80-8679543-8, Praha

Penzeš, L. (1996). Občan a bezpečnost (Citizen and Safety), Eurounion, ISBN 80-85858-41-X, Praha 